\title{
Problems of interpretation by
}

the European Court of

Justice of community

legislation on equal treatment

for men and women

\author{
by Judge Jean-Pierre Puissochet
}

Writing as a practitioner of the interpretation of Community law, I have limited this article to an illustration, through concrete examples, of how the European Court of Justice proceeds on the basis of provisions dealing with equal treatment for men and women, and of the types of difficulties encountered in this process.

B efore examining the relevant case law, I would like to make four very brief points in order to clarify the general background. First, a single method of interpretation is followed by the ECJ whether dealing with gender discrimination or with other issues. It is well known that this method is called 'teleological' and 'systemic', a grand terminology which refers in fact to simple notions, which are as follows. When doubts occur about the significance of a term or phrase, the selection of the proper understanding is performed with regard to the object and purpose of the provision itself and of the piece of legislation of which it forms part; this is the 'teleological' side. As for the 'systemic' approach, it means that, in addition to the above approach, some guidance is sought by studying how the provision relates to other notions in the same text, and how it best makes sense in the structure and general economy of the document in which it is inserted and of Community law as a whole.

Although the ECJ does not always look at the preparatory work to find out the original intention of the legislator, a secondary type of relevant information is occasionally found in the context, be it cultural, political, diplomatic or other, in which the rule in question was adopted. Finally, some useful hints can also be obtained through the comparison of the linguistic versions, (which are not always one hundred per cent coherent) in which the text was negotiated and passed.

My second initial point is that the implementation of this method varies to a great extent depending on whether the drafting of the provisions under consideration is of a general, almost philosophical, nature, like the wording of the European Convention on Human Rights -which forms part of Community law - or is very specific and carefully articulated in detail, with explicit limitations of the field of application, like Community regulations on social security. The function of a judge is essentially different when he or she is required to act as a secondary legislator and to indicate the scope and meaning of rights enunciated in an abstract fashion, when his or her task is clearly much more limited and should not conflict with the prerogatives of the legislative and regulatory powers. It is not always easy for the European judge in equal treatment cases, to determine which attitude is more suitable in a given situation - for example, when there are both general provisions and circumscribed regulations applicable to a case, which is not uncommon.

My third proviso is a reminder that, with exceptions, the ECJ, whose duty it is to decide on the interpretation and validity of $\mathrm{EC}$ legislation, is not there to interpret national law; in particular when a question is addressed to the Court by a national judge through a reference for a preliminary ruling. However, to decide whether an element of national legislation is compatible with EC law, it is necessary to know the actual scope and meaning of this element; but this determination is within the competence of the national judge alone and the court does not verify the accuracy of the presentation of the internal legal situation by the author of the referral is accurate. Nor, for this reason, does it declare the system of a Member State compatible or not with EC law. It simply 
states that a particular article or principle of Community law does (or does not) preclude a national rule.

The separation of functions between national and Community judges does not apply, of course, to direct actions in which the court may be asked, by the Commission or another Member State, to decide whether or not a state has failed to comply with its obligations to implement Community law on a specific matter, such as gender discrimination. Such actions imply an element of direct control, including the interpretation of provisions of national law. Yet, there are very few such cases in the relevent area; and almost all cases I have been through when preparing this contribution were references under Art. $177 / 234$ of the EC treaty.

My last point of introduction is that discrimination cases are rather numerous in the case law of the court and take more and more of its time; more at any rate than the inexperienced observer might think, considering that such issues are more directly related to the cultural evolution of modern societies than to the economic integration of Member States, for which the Community was originally given competence. This shows, first, how Community law pervades our daily life and, second, how fundamental the principle of equal treatment has become in the culture of labour law.

In addition to that, the geographical distribution of references for preliminary rulings in this area is relatively unbalanced since the United Kingdom and Germany are the origins, in similar numbers, of about 80 per cent of the selection of references I have been through, with the few others emanating from French or Austrian courts. It would be ludicrous to assume that more discrimination problems exist in these countries than among their partners. The imbalance can probably be more safely attributed to the degree of awareness of the legal professions and to the activism they demonstrate regarding these issues.

The three main areas in which problems of interpretation currently arise for the court are (1) equal treatment regarding access to employment and working conditions, (2) equal pay and (3) non-discrimination according to sexual orientation.

\section{EQUAL TREATMENT}

The principle of equal treatment is defined by the Equal Treatment Directive 1976 as meaning that

'there shall be no discrimination whatsoever on grounds of sex, either directly or indirectly, by reference in particular to marital or family status ... as regards access to employment, including promotion, and to vocational training and as regards working conditions'

However, the Directive does not apply to activities 'for which, by reason of their nature or the context in which they are carried out, the sex of the worker constitutes a determining factor'(Art. 2(2)) and allows 'provisions concerning the protection of women, particularly as regards pregnancy and maternity' (Art. 2(3)). It is also without prejudice to measures enacted to promote equal opportunities (Art. 2(4)).

Since the entry into force of the Treaty of Amsterdam, the prohibition of discrimination based on sex has been inserted in Art. 13 of the EC treaty as a fundamental right. But it is on the basis of the Directive that the case-law has been established. The principle has been invoked in cases of refusal to employ women, in particular in the army and in the police. I would like to say a word, in this connection, of the Johnston, Sirdar and Kreil cases.

In the case of Marguerite Johnston $v$ Chief Constable of the Royal Ulster Constabulary, 15 May 1986 (222/84) [1986] ECR 1651, Johnston was a member of the Royal Ulster Constabulary full time reserve who, following the decision of the Chief Constable that men, due to the situation in Northern Ireland, would carry firearms in the course of their duties but that women would not be so equipped, was not offered a renewal of her contract with the RUC. The Industrial Tribunal of Northern Ireland referred to the court, among other points, the issue of the interpretation of the exceptions contained in the 1976 Directive in a context characterised by threats to national security and public safety.

Advocate General Darmon expressed the opinion that the exclusion of women from employment as armed members of a police reserve could, in exceptional circumstances relating to public order, fall within the scope of the derogation provided for in the Directive and that it was for the national judge to determine whether, in the present case, the derogation was acceptable. The court ruled that there had to be judicial control over this type of derogation, which could find its basis only in the provisions of Art. 2 of the 1976 Directive, even if the protection of public safety was at stake. The judgment accepts that, although it must be interpreted strictly, the exception concerning activities 'for which the sex of the worker constitutes a determining factor' allows a Member State to restrict, on the basis of Art. 2(2), general policing duties to men equipped with firearms, in an internal situation characterized by frequent assassinations. It makes clear, however, that the derogation concerning the protection of women (Art. 2(3) does not apply since it covers only situations in which risks and dangers exist that affect women as such.

The same 'tolerant' or 'understanding' approach was also followed by the court in the case of Angela Sirdar v Secretary of State for Defence, 26 October 1999 (C273/97) [1999] 3 CMLR 559. Sirdar had served as a chef in the British Army when she was made redundant for economic reasons. She was initially offered a transfer to the Royal Marines, also as a chef, but was eventually informed that she was ineligible, since the Royal Marines 
employed only men by reason of the rule of 'interoperability' established for the purpose of ensuring combat effectiveness. The reference by the Industrial Tribunal at Bury St Edmunds, was, again, focused on the notion of 'determining factor' in Art. 2(2) of the Directive. The court's decision stresses that the review of the use made of the derogation by the authorities of a Member State must be based on proportionality. The ruling, considering that the Royal Marines are a small force representing the first line of attack of the British armed forces, accepts that chefs are also required to act as front-line commandos and that the composition of this force can be exclusively male; and that this exclusion is appropriate and necessary to achieve the aim of guaranteeing public security. This aim grants the Member State a certain degree of discretion to assess the need to maintain the exclusion in the light of social developments.

After this ruling, it was not without some disappointment that the German armed forces received the judgment of the court in the case of Tanja Kreil $v$ Germany, 11 January 2000 (C-285/98) The Times, 29 November 2000. But the German Soldatengesetz, referred to the court by the Verwaltungsgericht Hanover, was vastly different from the provisions considered in the previous cases, in so far as it excluded any woman from armed service in the whole Bundeswehr and allowed them to be engaged only in the medical and military-music services. The court did not accept that the mention of public security was sufficient to give a Member State discretion to exclude women from almost all military posts in armed units. The court rejected the justification offered regarding the fact that members of the forces may be called on to use arms and regarded the national measure as contravening the principle of proportionality.

Discrimination in access to training is also banned by the Directive. This matter has been addressed by the Court in the case of Schnorbus $v$ Land Hessen, 7 December 2000 (C-79/99) [2001] 1 CMLR 40.

Julia Schnorbus, after completing her legal studies, applied for admission to the practical training necessary to obtain a post in the judicial service or the higher civil service in Land Hessen (Germany). She was not immediately accepted for this training, on the basis of provisions allowing the admission to be deferred by up to 12 months except for applicants who have completed military or substitute service (which is obligatory only for men) who have to be admitted immediately.

On the questions asked by the Verwaltungsgericht Frankfurt, the court had no difficulty in recognising that the law of Land Hessen was favourable to men having accomplished military or civilian service and thus constituted indirect discrimination based on sex. It went on to examine whether this discrimination was justified under the derogation contained in Art. 2(4) of the Directive concerning measures intended to promote equal opportunities. The examination revealed no intention behind the provision except that of counterbalancing to some extent the career delay resulting from the completion of compulsory service by men. The difference of treatment among applicants for legal training, never exceeding 12 months, was therefore regarded as proportionate and compatible with equal treatment.

The Directive also guarantees, in Art. 5, equal treatment in the conditions governing dismissal.

In Bärbel Kachelmann v Bankhaus Hermann Lampe KG, 26 September 2000 (C-322/98) [2001] IRLR 49, Kachelmann, who was employed by a German bank on a part-time basis for 30 hours a week, was dismissed on economic grounds. In order to select the worker to be dismissed on social criteria, as German law required, the bank only considered part-time employees. Mrs Kachelmann claimed, before the Landesarbeitsgericht Hamburg, that this constituted discrimination as women were substantially more numerous than men in the category of part-time workers. Besides, she mentioned that another female worker, who was working full-time, should have been dismissed instead of her, as she had priority over her on the basis of social criteria.

The court was asked to decide whether the Directive precluded social legislation under which, to select employees for dismissal, part-time female employees were not regarded as comparable to male and female full-time employees. The court accepted that there was a difference of treatment between full-time and part-time workers but that social policy was presently a matter for the Member States and that social protection measures were within the margin of discretion of governments. as long as they met a legitimate aim and were justified by factors unrelated to sex. The court noted that such justification existed, simply adding that it was a matter for the national legislature to find a fair balance in employment law between the various interests concerned.

Measures intended to promote equality by giving priority to women have given rise to such famous decisions as Kalanke, Marschall and Badeck.

In Eckhard Kalanke $v$ Freie Hansestadt Bremen, 17 October 1995 (C-450/93) [1995] ECR I-3051, Kalanke was a candidate for a post of section manager in the Parks Department of the City of Bremen (Germany). He was not given the job because the other shortlisted candidate, who was considered equally qualified to him, was a woman and was therefore given the preference by application of the Landesgleichstellungsgesetz (Bremen Law on equal treatment).

Following a reference by the Bundesarbeitsgericht, the court noted that a national rule under which women are automatically given priority in sectors where they are under-represented, when equally qualified as male candidates for the same promotion, involved 
discrimination on grounds of sex. To decide whether this rule was permissible under Art. 2(4) of the Directive, concerning 'measures to promote equal opportunity for men and women, in particular by removing existing inequalities which affect women's opportunities', the court explained that the measures concerned by the derogation were those intended to eliminate or reduce actual instances of inequality existing in social life by giving a specific advantage to women competing in the labour market. But this derogation should be interpreted strictly and should not go beyond what is required to improve women's opportunities. Stating that women will automatically get the job if they do not make up at least half of the staff in the relevant personnel group, and if they have the same qualification as their male competitors, is a rule that is too absolute and too unconditional to fit within the limits of the exception. Instead of improving the conditions of competition, it suppresses competition altogether. It is therefore precluded by the Directive.

The case of Helmut Marschall $v$ Nordheim-Westfallen, 11 November 1997 (C-409/95) [1998] IRLR 39, gave the court an opportunity to set the limits of this area of case law by indicating the conditions under which affirmative action was acceptable in the field of job competition. He was a teacher for the Land Nordrhein-Westfalen (Germany) and, again, was refused a promotion which was given to an equally qualified female colleague. The legislation concerned was not as blunt as that in Kalanke since it gave priority for promotion to women (when under-represented) 'in the event of equal suitability, competence and professional performance, unless reasons specific to an individual male candidate tilt the balance in his favour'.

The court found merit in the final proviso of this clause and ruled that a provision such as that under consideration was compatible with the 1976 Directive, on condition that the candidature of an equally qualified male must be subject to an objective assessment, taking into account all criteria and not excluding the possibility that the priority for women might be overruled in his favour. In other words, there could be no a priori preference, but must be a case-by-case consideration of the merits is in order.

In Re Georg Badeck's Application, 28 March 2000 (C158/97) [2000] IRLR 432 and others are members of the Landtag of Hesse (Germany) who questioned the constitutionality of statutory provisions regarding women's advancement plans and their conformity with the 1976 Directive. The Staatsgerichtshof des Landes Hessen referred to the court five separate issues which I cannot explain in detail here, but which cover the limits of priority, the targets of the plan, the allocation of training places, the organisation of interviews, and the composition of representative bodies. Suffice it to say that the court expanded on the reasoning at work in the Marschall case.

\section{EQUAL PAY}

Equal pay is an area covered by different Community law provisions. Article. 141 (ex 119) of the EC treaty states that 'each Member State shall ensure that the principle of equal pay for male and female workers for equal work or work of equal value is applied' and further defines what is meant by 'pay'. Para. 4 of the article safeguards the possibility to prevent or to compensate for disadvantages in professional careers through specific measures in favour of the under-represented sex.

The Equal Pay Directive 1975 complements these provisions of primary law. Out of a substantial body of case law, I will limit myself to three recent examples of interpretation by the court of the relevant notions.

The Austrian case of the Angestelltenbetriebsrat der Wiener Gebietskrankenkasse, 11 May 1999 (C-309/97) [1999] ECR I-2865 deals with the meaning of the words 'the same work' contained in Art. 141 EC and in Art. 1 of the 1975 Directive. The dispute which the Oberlandesgericht Wien had to settle was between a Health Fund and one category of persons employed by the Fund as psychotherapists. Graduate psychologists, employed as psychotherapists, were complaining that they were not placed in the same salary group as doctors, employed - according to them - to do 'the same work'. It so happened that more women than men were present in the category of psychologists than in that of doctors.

Discrimination being defined as the application of different rules to comparable situations or the application of the same rule to different situations (Gillespie $v$ Department of Health and Social Services, 13 February 1996 (C-342/93) [1996] ECR I-475) the difficulty often met is in the description of the groups of reference. In the present instance, the difference lay in the fact that the members of each group had received different training. The court acknowledged that professional training and qualification could be a relevant criterion for determining whether the same work was performed. Although the activities of all psychotherapists were 'seemingly identical' and charged according to a single tariff, the difference between the knowledge, skills and expertise for which they have been recruited, either as doctors or as psychologists, made it impossible to regard their situation as comparable or the work they performed as the same: and this made the difference of salary compatible with the relevant EC provisions.

In the case of Shirley Preston and others $v$ Wolverhampton Healthcare NHS Trust (No. 1), 16 May 2000 (C-78/98) [2000] IRLR 506, who were part-time workers in the United Kingdom in the public and private sectors who, following previous rulings by the court, in the Vroege and Fisscher cases, claimed that their exclusion from occupational pension schemes on the ground that they worked part-time had been unlawful and discriminatory because (as was not disputed) it concerned 
a much greater number of women than men. They also claimed that they ought to be retroactively entitled to membership of the relevant pensions schemes for the periods of part-time employment they had completed before the national legislation was adjusted to fit the requirements put forward by the court.

The ruling in this case, answering a complex series of questions raised by the House of Lords, embodies the principle of effectiveness and equivalence that must prevail in the guarantee of rights derived by individuals from Community law, in particular compared with rights of national origin. It replies, in particular, that EC law does not preclude a time-limit of six months after the end of employment for claiming membership of a pension scheme, given that domestic law does not contain more favourable provisions for similar actions; and that the six months period is calculated, in the case of successive short-term contracts, not from the end of each contract but from the end of the whole period of employment. This example shows how far the judge must sometimes go in the review of the consequences of his theoretical pronouncements.

Joseph Griesmar brought to the French Conseil d'Etat, which addressed a reference to the court, an apparently more straightforward issue which is still pending in Luxembourg - which prevents me from saying anything about the case except about the terms of the debate as they are mentioned in the opinion of Advocate General Alber of 22 February 2001 (Griesmar case, C-366/99). To put it briefly, the plaintiff, a member of the French judiciary who has retired, claims that his retirement pension is calculated in a manner contrary to the principle of equal pay between men and women, since the national statute concerning the pensions of civil servants grants women who have had children an additional pension benefit corresponding to a year of employment for each child they have borne. As the father of three children, Mr Griesmar regards the fact that he did not receive the same benefit as a discrimination falling under Art.141 EC. M Alber concludes for his part that the provisions of national law do not go against the principle of equal pay. We may expect a very vivid discussion of this problem by the court.

I may only mention in passing the judgment in the Abdoulaye $v$ Regie Nationale des Usines Renault SA, 16 September 1999 (C-218/98) [1999] IRLR 811 case as it illustrates a central concept in the court's approach to salary benefits reserved to women. The court ruled that Art.141 (ex 119) 'does not preclude the making of a lump-sum payment exclusively to female workers who take maternity leave where that payment is designed to offset the occupational disadvantages which arise for those workers as a result of their being away from work'.

\section{DISCRIMINATION ACCORDING TO SEXUAL ORIENTATION}

Let me pass now to the few, but very well-known, cases dealing with alleged discrimination, not on grounds of the gender of the person concerned, but on grounds of his or her sexual preferences or orientations. I realise that it is debatable whether this is the best way to present the issue, since one of the legal points under discussion is whether differences of treatment based on the sex of the partner, and more specifically on whether or not the partner is of the same sex as the person concerned, are discriminations based on sex or another form of discrimination.

This puts in question the respective role of the judge and the legislator in areas that involve choices of social evolution. It is symptomatic in this respect that, where the European Court of Human Rights never hesitated to give very broad definitions of the terms of its instrument of reference, the Court of Justice has always been more careful in its desire not to interfere with social decisions that, in its view, should result from the people's will rather than from an arbitrary expansion of the field of application of principles. But this puts the Luxembourg Court in an uncomfortable position, because it should implement the ECHR as forming part of EU law under Art. 6 of the Treaty on European Union, and it is inconceivable that the interpretation of the Convention should be conducted without reference to the case law of the Strasbourg Court.

The case of $P$ v $S$ and Cornwall County Council, 30 April 1996 (C-13/94) [1996] ECR I-2143, is often misinterpreted. $\mathrm{P}$ was a manager in an educational establishment in Cornwall who, although physically of the male sex, first started dressing and behaving as a woman before taking the physical attributes of a woman after undergoing surgical operations. He was given notice and dismissed. The Industrial Tribunal at Truro referred to the court the question whether the dismissal of a transsexual by a reason related to gender reassignment was a breach of the 1976 Directive on equal treatment.

The court ruled that it was; but, contrary to what overenthusiastic commentators held, this ruling had nothing or little to do with sexual orientation, being instead a direct case of gender-based discrimination. As the motives indicated in point 21 , 'where a person is dismissed on the ground that he or she intends to undergo, or has undergone, gender reassignment, he or she is treated unfavourably by comparison with persons of the sex to which he or she was deemed to belong before undergoing gender reassignment'. a difference of treatment between the two genders, be they contained in one single individual, is a direct discrimination : As a male person, $\mathrm{P}$. had the job; after his gender change, he lost it.

The lawyers who inferred from $P_{V} S$ that the so-called 'generous' outlook taken by the court regarding transsexuals would certainly be extended to homosexuals 
were wrong, because the two issues are entirely separate in legal terms.

In the case of Lisa Grant $v$ South-West Trains Ltd, 17 February 1998 (C-249/96) [1998] ECR I-621, Grant was a female employee of South West Trains Ltd who was refused travel concessions for her female partner, where privilege tickets would have been granted had her partner been of the opposite sex. She regarded this state of affairs as discrimination based on sex, violating inter alia Art. 119 of the EC treaty and the 1975 and 1976 Directives. The Industrial Tribunal at Southampton referred the question of interpretation of these provisions to the ECJ.

The court, basing itself on Community law as it stood before the entry into force of the Amsterdam Treaty, did not characterise the treatment to which the plaintiff was submitted as amounting to a gender-based discrimination. It first noted that the refusal of travel concessions to the same-sex partner was not directly based on the sex of the employee (contrast the $P_{V} S$ case) or even on the sex of the partner, but rather on the character of their relationship: homosexual and not heterosexual. The court went on to check whether an assimilation in rights of homosexual relationships to heterosexual ones was an integral part of the state of law in the Community at the relevant time. Taking into account not only Community instruments, but international law, European Human Rights law and the law of Member States, the court concluded that it was not in a position to recognise the existence, de lege lata, of such an overall assimilation. However it noted that the issue was in the hands of the legislature, to whom the Amsterdam Treaty gives a legal basis to take appropriate action to eliminate discrimination based on sexual orientation.

I can hardly conclude my picture of the jurisprudence without mentioning a case in which the ruling will be issued on 31 May and, therefore, cannot be commented on yet. The opinion by Advocate General Mischo of 22 February 2001 (C-122/99P and C-125/99P) D and Sweden $\checkmark$ Council cases pose the problem of members of the Community personnel who claim the benefit of the family allowance which the statute provides for married agents, whereas they have entered into a legally registered homosexual partnership to which the Swedish national law attributes similar effects to that of marriage. The situation is even more complex in the case of the Netherlands who have now made it possible for people of the same sex to be literally 'married'.

The court is faced with a problem of interpretation of the terms of 'marriage' and 'married' contained in a Council regulation but dealing with a subject matter that of the legal status of persons - which has not been transferred to the Community by the Member States. The Council could legally have decided to extend the benefit of the allowance to homosexual partners legally recognised in a Member State; but, this not being the case, the option of the court is either to regard the terms as making implicit reference to the law of the country of origin of the staff member (which implies that they will have different interpretations) or to rule that terms contained in the staff statute must have a single meaning - which means that the court will have to provide a Community interpretation of what is a marriage and of whether it may be open to people of the same sex. A difficult determination, if ever there was one, for a judge trying not to interfere excessively with the prerogatives of the legistator!

I intend to draw no conclusion from this pragmatic description of the main discrimination issues currently concerning the court - save perhaps to draw your attention to a technical point that I have left in the background but which might deserve a better place in another paper. I have in mind the question of the drafting of references by national courts for preliminary rulings on the interpretation and validity of EC antidiscrimination law. It is clear that, if we compare the various cases I have just listed, there is an enormous difference between the very specific language used by, say, UK courts (like the reference by the House of Lords in the Preston case) and the succinct formulation used, say, by the Conseil d'Etat in the Griesmar reference. Both methods are precise, but one leads the court to start from the characteristic elements of a given situation to see how it can best be addressed in a concrete fashion, while the other encourages it to expand on the theoretical character of a legal concept before applying it to a case.

Of course, the court has the freedom to reformulate the questions posed, and differences of style in referrals are not binding on the Community judge. However this judge will hesitate to depart too openly from the wording used by a supreme court of a Member State. The degree of influence thus exercised by referring judges on the way Community law is interpreted by the ECJ, regarding in particular the doctrine of precedent, should not be under-estimated. This is particularly true in areas like equal treatment where both general principles and detailed specifications are part of the picture.

Judge Jean-Pierre Puissochet

Counsellor of State, Judge of the European Court of Justice

This article is taken from a paper given at a Statute Law Society Conference held at Jean Moulin University, Lyon, on 12 and 13 May, 2000, on the theme of 'Anti-Discrimination Legislation in Europe: Issues of Drafting and Interpretation'. 